\title{
Upbringing of Girls as Reflected in the Activities and Views of Blessed Marcelina Darowska
}

\begin{abstract}
The article presents the life and educational activities of Blessed Marcelina Darowska, the co-founder of the Convent of the Immaculate Conception of the Blessed Virgin Mary, and her views on upbringing of young women. Mother Marcelina's perception of education of girls in the $19^{\text {th }}$ century seemed modern and beyond her time. In her opinion, there was a need of putting a stop to producing "parlour dolls" and provide young women with practical education. For the betterment of the country, she set up schools in Jazłowiec, Jarosław, Niżniów and Nowy Sącz. The girls attending the schools were brought up according to the system developed by Marcelina Darowska, based on religious and patriotic values. The Convent of the Immaculate Conception of the Blessed Virgin Mary continues the work commenced by its founder; over time Mother Marcelina's message remains valid and serves the subsequent generations of young Polish girls.
\end{abstract}

Keywords: Marcelina Darowska, Convent of the Immaculate Conception of the Blessed Virgin Mary, Catholic schools, education of women in the nineteenth century

\section{The life and educational work of Marcelina Darowska}

Marvelina Darowska née Kotowicz was both on the $16^{\text {th } 1}$ of January 1827 , as the fifth of seven children of Jan Kotowicz and Maximilia Jastrzębska. Raised in a wealthy landowner's family on the Szulaki estate in the Kyiv² province, even as a child, she showed

\footnotetext{
${ }^{1}$ According to the Julian calendar, which was then used in Russia. According to the Gregorian calendar, which was used in the West, it would be the 28th of January. Due to the fact that Marcelina's birth record was lost, the date of her birth was determined on the basis of her memoirs written by Fr. Kajsiewicz in the years 1859 1869. Coś co poprzedziło. Autobiografia (Kilka lat z życia Matki Marceliny przez nia same spisane), Immaculate Sisters Congregation Archive (hereinafter abbreviated as ISCA), sign. P.20.1.I.1.

2 These were the lands located in the so-called Western Krai, sometimes referred to as the Taken Lands the territories of the former Republic of Poland, which, as a result of these were the lands located on the so-
} 
patriotic feelings towards the enslaved country and a great sensitivity to social issues ${ }^{3}$. In accordance with the standards of the time, she was initially educated by nannies and governesses, who often changed and did not have a thorough knowledge. At the age of 12, Marcelina was sent to Odessa with her older sister Cezaryna. There, they were educated on the salary run by a Swiss woman, Mrs Schedoeuver. This facility was cosmopolitan and had a rigorous approach to educational issues. When Marcelina recalled her stay at the school many years later, she said: "no one looked at the heart there, no one studied feelings, it was all about external decency, learning your lessons, tidying up the classroom, and the dancing and singing that you were supposed to show off at the exam"4.

During her stay in Odessa, the teenage Marcelina began to consider joining a religious order. However, she was aware that her parents would not have accepted such a decision. She told her trusted catechist, Father Anzelm, about her plans. Bearing in mind the possible opposition of Marcelina's parents, the clergyman convinced her that a good secular life was more useful than living in a convent and that it would contribute more to her future salvation. Eventually, after completing her studies, the 15-year-old Marcelina returned to her native Szulaki ${ }^{5}$.

While living in her family home, Marcelina helped her father to manage the land property and dedicated herself to social work on behalf of the local population. She personally taught the children catechism, nurtured the sick and supported those in need. She raised money to help the poor through her father's office, her own sacrifices (e.g. giving up new dresses) and unofficial subsidies from her mother. While taking care of others, Marcelina did not forget her own development either. She was intensively educated, mainly through reading various books ${ }^{6}$.

Despite her initial reluctance to marry, Marcelina finally changed her attitude under the influence of her father, who was seriously ill, and made her promise that she would get married. Jan Kotowicz recovered, but Marcelina still felt bound by the pledge she had made and she married Karol Darowski, who had been courting her for years, on

\footnotetext{
called "greenfield". The Prohibited Provinces, also known as the Prohibited Territories, i. e. the territories of the former Republic of Poland, which, as a result of three partitions belonged to Russia and did not become part of the Kingdom of Poland. Poles sometimes referred to these lands as the Grand Duchy of Lithuania and Rus. In the 1930s the term "Borderlands" became popular, which in the past meant lands in the "Ukraine", i.e. on the border of the Republic of Poland. Poles treated this area as their land, which was taken away, other nationalities living in these areas also considered it as their property and they did not accept the Polish claims to them. In turn, according to the name given by Petersburg, these lands constituted the North-Western Krai (Lithuania and Belarus) and the South-Western Krai (Kievan lands). Until 1840, the terms "western provinces" or Lithuanian, Russian and Belarusian provinces were also used. Their use was abolished, as they implied the non-Russian character of these areas. After: CHWALBA, A., Historia Polski 1795-1918, Krakow 2000, pp. 202-203.

${ }^{3}$ Cf. DAROWSKA, M., Coś co poprzedziło, op. cit., pp. 8-9.

4 Ibidem, p. 17.

5 Ibidem, p. 22.

${ }^{6}$ Wspomnienia Cezaryny z Kotowiczów Zakrzewskiej (siostry Marceliny). Podyktowane wnuczce Janinie i przestane siostrom niepokalankom w 1906 r., ISCA, sign. P.93a.1.I.1.
} 
the $2^{\text {nd }}$ of October (the Feast of the Guardian Angels) $1849^{7}$. After the wedding, she settled with her husband and his brothers in Tetyjów. Over time, she gave birth to her son Joseph (1850) and daughter Anna Karolina (1852) were born. The family happiness was interrupted by the unexpected death of Karol (April 1852) and their son Joseph (January 1853). Marcelina understood then that family life had never been meant for her. She described this breakthrough moment in the following words: "kneeling at a smiling child's catafalque, all in pain, but calm, I felt broken for the second time - but not only in human happiness, as before - because this was not for me - but on the path I walked through the world. I felt internally, as if in a revelation, that God's will had not intended the way of the world for me, that the religious life was my destiny: I had left it and the circle that I had to make to return to it was thorny and bloody" .

Focused on devoting herself to spiritual life, Marcelina went to Germany and then to Rome. There, she also made contact with Father Hieronim Kajsiewicz and Józefa Karska, and became involved in the organization of the religious congregation, which would be educational in nature. The newly formed community received an official legal act from the ecclesiastical authorities on the $25^{\text {th }}$ of November $1857^{9}$ and was gathered under the patronage of the Immaculate Conception of the Blessed Virgin Mary. When the congregation was given its name, Józefa Karska she assumed the title of mother superior, and the previous candidates were given identical grey dresses ${ }^{10}$. Only Marcelina remained in secular clothes. After the death of Józefa Karska on the $11^{\text {th }}$ of October 1860, Marcelina assumed the duties of mother superior ${ }^{11}$.

The congregation was created with the goal of bringing up girls to be Christian wives, mothers and citizens, in order to bring about the regaining of Poland's lost independence through rebuilding families. Consequently, Marcelina Darowska, when considering the possibility of setting up the first convent of the Sisters of the Immaculate Conception outside of Rome, she paid special attention to the situation prevailing at that time in each of the partitions. Galicia stood out with the greatest autonomy. Eventually, Mother Marcelina decided to set up a house of assembly and an educational institution for girls in Jazłowiec, a town $250 \mathrm{~km}$ from Lviv ${ }^{12}$. Under the agreement concluded with Krzysztof Błażowski,

\footnotetext{
7 Darowska, M., Coś co poprzedziło, op. cit., p. 27.

8 Ibidem, p. 28.

9 The date is known as the date of founding of the congregation. Cf. KOSYRA-CIEŚLAK, H., SZYMCZAK, R., Poszłam siać do Polski...i wzeszło, vol. 1, Szymanów, 2004, p. 21.
}

${ }_{10}$ Marcelina, as a Russian subject, was threatened with forfeiture of all her assets for her participation in an "illegal" (from the standpoint of tsarist laws) religious congregation. Cf. JABŁOŃSKA-DEPTUŁA, E., Marcelina Darowska Niepokalanka 1827-1911, Lublin, 2010, pp. 47-48.

11 SoŁtAN, M.A., CIC, Stużebnica boża Marcelina Darowska, [in:] J.R. BAR (ed.), Polscy święci, vol. 8, Warsaw, 1987, p. 207.

12 Jazłowiec - in the past, due to its location near the trade route, the town was often the target of Tatar raids. The place is also where the ruins of a medieval castle, once owned by the Koratowicz family, and then by the Buczacki family of the Habdank coat of arms (they assumed the name Jazłowiecki) were located. After Jan Sobieski liberated the place from the Tatars' hands, its new owner Aleksander Koniecpolski built a white palace near the old ruins, which was called the "lower castle" in order to distinguish it from the old castle. In 1746 
the Congregation of the Sisters of the Immaculate Conception of the Blessed Virgin Mary received the building of the former Poniatowski Palace and the ruins of the medieval castle, together with the surrounding garden free of charge. In return, the Sisters would provide free education at their school for a girl named by the donor family ${ }^{13}$.

Despite the initial difficulties and the lack of official government permission, Marcelina launched a three-class ${ }^{14}$ secondary school in Jazłowiec on the $1^{\text {st }}$ of November 1863 , with a 6-year course of study. At the time, seven girls began their studies at the school, including Marcelina's daughter. The first boarding school of the Sisters of the Immaculate Conception charged tuition, because the sisters could not count on any financial support from the Austrian authorities. In the following year, Mother Marcelina also established a free primary school for children from the surrounding area ${ }^{15}$.

Starting in 1889, the Jazłowiec's pupils who wanted to work as teachers in the future were additionally prepared for the governmental teacher's examination. In 1893/4, an eighth grade was created in Jazłowiec and three years later, an optional ninth grade was created, which functioned when there were enough willing candidates. The eighth grade completed the general education and it was attended by students from all the other schools run at that time by the sisters. With the entry into force of the 1906 government law, which made it possible for secondary school graduates to continue their education at universities, Mother Marcelina decided to adapt her curriculum to that of government schools. The first students from Jazłowiec passed their maturity examinations in Lviv in $1907^{16}$.

Due to the large number of students in Jazłowiec ${ }^{17}$, Mother Marcelina decided to set up an institution in Jarosław. The new school was built from scratch on the spot where the Jesuit monastery had been and where Piotr Skarga wrote The Lives of the Saints and Sejm Sermons ${ }^{18}$. Despite financial difficulties, the owner's reluctance to sell adequate land and

both buildings changed hands and were owned by the Poniatowski family and according to the local legend, the first plan of the Targowica Confederation was created in the reception hall of the castle. After the First Partition of Poland, the Jazłowiec estate was bought by the Potocki family, who, having lost their fortune, had to hand it over to Grudnicki, their plenipotentiary. Ultimately, Jazłowiec became the property of the Błażowski family. After: SZEMBEK, Z., CIC, Jazłowiec, Jazłowiec 1938, pp. 8-9; KOSYRA-CIEŚLAK, H., SZYMCZAK, R., Poszłam siać, op. cit.,,vol. 1, pp. 55-58.

13 SOŁTAN, M.A. CIC, Matka. Życie i działalność Matki Marceliny Darowskiej 1827-1911, Szymanów, 1982, p. 114.

${ }^{14}$ Subsequent senior grades were to be created with the transition of students to subsequent levels of education. In addition, six years after the opening of the school, a complementary seventh grade was introduced. Cf. JABŁOŃSKA, E., “Zarys działalności Matki Marceliny Darowskiej na polu organizacji szkolnictwa żeńskiego 1863-1911”, Nasza Przeszłość 1958, vol. 7, p. 224.

15 SKÓRZEWSKA, G., CIC, Zapiski o Matce naszej, ISCA, sign. F VII 1, vol. 10.

16 SZEMBEK, Z., CIC, op. cit., pp. 67-68.

${ }^{17}$ In 1874, 50 students attended the school in Jazłowiec. With time, when the additional seventh and ninth grade were opened, Mother Marcelina increased the limit of number of girls attending the Congregation schools from 60 to 70 . After: ibidem, pp. 41, 48.

${ }_{18}$ The history of Jarosław was presented in: KOSYRA-CIEŚLAK, H., SZYMCZAK, R., Poszłam siać, op. cit., vol. 1, p. 202. 
lack of building materials, the sisters began their activities at the boarding school and primary school in Jarosław on the $1^{\text {st }}$ of October $1875^{19}$. The didactic and educational work in both schools took place in the same spirit and on the basis of the same principles as in Jazłowiec. The only innovation in the field of education was the opening of an additional seventh grade (previously, a six-year course had been conducted in Jazłowiec) ${ }^{20}$.

Another institution of the Sisters of the Immaculate Conception was established in 1883 in Niżniów, with a view to free teachers' education, for girls coming from impoverished families of the nobility and daughters of meritorious patriots who had participated in the struggle to regain independence. Mother Marcelina hoped that in the future, the Niżniów students would replace the governess brought in from abroad and would educate and shape the generations of young Poles ${ }^{21}$.

The owner of the monastery building, Stanisław Lanckoroński, agreed to hand it over free of charge to the sisters for the seat of the new school, because he was familiar with the educational activity of the congregation ${ }^{22}$. However, the sisters had to face a number of difficulties related to the costs of renovating and adding more buildings, but above all to the protests of local householders and the complaint of the then administrator of the parish filed with the tax office. Thanks to Mother Marcelina's personal involvement, however, the work was completed and the first children were admitted to the Niżniów school on the $4^{\text {th }}$ of November 1883 . Despite a lack of understanding among part of the society, the sisters operated the school in Niżniów, providing the girls with a seven-year education, along with pedagogical internship, during which the alumni worked at the oldest school of the congregation in Jazłowiec ${ }^{23}$.

After the foundation of three schools in Galicia, Mother Marcelina considered the possibility of founding a school in the Prussian partition. However, her intention turned out to be impossible because she did not have influential protectors, and the partition authorities did their best to prevent all activities supporting Poles. That is why she finally decided to purchase land near Nowy Sącz, which she described as "the front-most hut in the direction of the Poznań region", ${ }^{24}$ and to begin the construction of another Sisters of the Immaculate Conception school. ${ }^{25}$

19 SOŁTAN, M.A., CIC, Człowiek wielkich pragnień. Matka Marcelina Darowska 1827-1911, Szymanów 1977, pp. 68-72.

${ }^{20}$ In the 1876/1877 school year, due to an extensive curriculum and teaching activities, an additional eighth grade was created to serve the role of the former complementary seventh grade. Cf. DAROWSKA, M., List do J. Felińskiego, 28.09.1876 (copy), ISCA, sign. P.8.2.I.46.

${ }^{21}$ S.M. EWA OF DIVINE MERCY, Nauczycielka życia. W hołdzie wdzięczności bt. Matce Marcelinie Darowskiej, Szymanów 2009, p. 13.

22 Both Stanisław Lanckoroński's daughter, Stefania Urbańska, née Lanckorońska, as well as his future daughter-in-law Franciszka Lanckorońska nee Masłowska were students of the Immaculatine school in Jazłowiec. After: JABŁOŃSKA-DEPTUŁA, E., Niepokalanki w polskim trwaniu, Niepokalanów 1993, p. 131.

${ }^{23}$ SOŁTAN, M.A., CIC, Matka. Życie i, op. cit., pp. 230-233.

24 SKÓRZEWSKA, S.G., CIC, Zapiski, op. cit., vol. 11.

${ }^{25}$ DAROWSKA, M., List do S. Józefy, 6.VII.1894, ISCA, sign. P.36.4.II.692. 
The seven-class secondary school with a humanities orientation and a free 4-class primary school in Nowy Sącz began operations in September 1897. The new institution soon began to be called the White Convent ${ }^{26}$. Taking into account the difficult situation of the population in the Prussian partition, Mother Marcelina guaranteed priority admissions to the school in Nowy Sącz for girls from Wielkopolska. Moreover, one place in the Niżniów school was reserved for a girl from the Poznan region every year ${ }^{27}$, while in the other schools of the Congregation, money was collected to help the disadvantaged and deprived of their own land estates ${ }^{28}$. Over the next nearly twenty years, the sisters educated and brought up new generations of girls in Nowy Sącz, according to the rules that applied in all schools of the Congregation.

When she set up another school in Galicia, Mother Marcelina continued to consider the possibility of extending the activities of the nuns to the lands of the other two partitions. Such an opportunity finally appeared, however, due to various dilemmas connected with undertaking business in Słonim (working with the underground), the decision to open another institution of the congregation was made, at Mother Marcelina's request, by Pope Pius X. Assigned to travel to the institution being set up were Sister Wawrzyna of the Offering of Our Lady, Sister Teresita of the Baby Jesus and Sister Klementyna of Mercy. The sisters had to meet formal and administrative requirements ${ }^{29}$ and prepare the neglected convent. Under the guise of participating in cleaning work, local girls also gathered and were taught in $\operatorname{secret}^{30}$.

Despite various precautions, the police grew increasingly suspicions about the nature of the activities carried out by the sisters in Słonim. The chance to open a two-class parish school or boarding school was becoming less and less realistic. At the same time, Mother Marcelina also strongly opposed the idea of opening a Russian school and running an "undercover" Polish school. Despite numerous efforts made by sisters ${ }^{31}$ over the next eleven years, their educational work was carried out in $\operatorname{secret}^{32}$.

${ }^{26}$ Stulecie Białego Klasztoru i Szkoły Sióstr Niepokalanek w Nowym Sączu, M.E. DOMASZEWSKA, M.E. GUŻDA, M.M. PINTSCHER CIC (eds.), pp. 13-25.

27 DAROWSKA, M., List do S. Filomeny, 3.XII.1901, ISCA, sign. P.39.2.II.736.

${ }^{28}$ Eadem, List do S. Filomeny, 8.XII.1901, ISCA, sign. P.39.2.II.737.

29 The sisters took steps to obtain permission to join the Bernardine congregation. The procedure was complicated and involved submitting an application to the governor in Grodno, who then sent it, together with his opinion, to the Governor General in Vilnius, and the final decision was taken by the Ministry of Confessions in St. Petersburg. According to the regulations in force, the candidate also had to undergo two "tests" carried out by local police officers. Cf. SOŁTAN, M.A., CIC, Stużebnica..., p. 225.

${ }^{30}$ Idem, Matka. Życie i, op. cit., pp. 241-242; 244-246.

31 Initially, Mother Marcelina tried to obtain permission for the official arrival of Immaculatines to Słonim and running a Polish school for girls jointly with the Bernardines. When this turned out to be impossible, she decided to open a school of crafts for extramural students. This idea has not been implemented either. Finally, a decision was made to open a weaving school there, similar to the school run by Anna Mohl in Livonia. Ultimately, however, this idea was not implemented. Cf. ibidem, pp. 242-243.

32 Idem, Matka Marcelina Darowska (1827-1911), [in:] Chrześcijanie, B. BEJZE (ed.), vol. 4, Warsaw, 1980, pp. 310-311. 
Another possibility of founding a school in the Russian partition presented itself before the decision was made to establish a school in Słonim. The sisters received an offer from Maria Ciechanowska to organise a secondary school for girls in the Kingdom of Poland. Despite the initial refusal of the authorities, the influential landowner personally obtained from Tsar Nicholas II permission for the arrival of 50 sisters of the Immaculate Conception and the establishment of an educational institution for girls, in which teaching and upbringing was to take place according to the Congregation programme. Determining a specific place of operation for the convent and the school of the Congregation became an important issue. The final choice was Szymanów, in the Sochaczew district, about 40 kilometres from Warsaw, and the palace with a park belonging to Konstanty Lubomirski located there ${ }^{33}$. After Mother Marcelina acquired it, however, the sisters could not start working there, because it had been previously leased for a year to Father Gralewski, who organized a boarding house for boys. Following the order received from St Petersburg to start the school year in the Kingdom in autumn 1907, Mother Marcelina decided to establish a three-class secondary school and a primary school in Komorów. A year later, on the $15^{\text {th }}$ of July 1908, the sisters moved to Szymanów ${ }^{34}$.

Along with the creation of the school in Szymanów, Mother Marcelina's desire came true, which she had repeated for a long time: "I would go to the Crown on foot, leaning on a stick." ${ }^{35}$ Less than two months after breaking her leg, leaning on a stick, the over 80-year-old Marcelina left for Szymanów to support the sisters in establishing a new foundation. Her presence was also necessary because of the poor health of the mother superior of the local house, Sister Ludwika, who died on the $15^{\text {th }}$ of September 1908, on the day of the blessing of the house in Szymanów and the arrival of the first pupils. The first school year in Szymanów began with 50 girls $^{36}$.

Mother Marcelina stayed in Szymanów until the spring of 1909, because the situation of the established school remained uncertain for a long time. The original assurance that the sisters would be able to run the school freely in accordance with its curriculum proved completely untrue. The Russian authorities constantly intervened in matter of teaching and upbringing. By orders received from Russian, history and geography lessons were taught in Russian and conducted by Russians, and the same requirement was made for Russian language classes, which were to be taught 10 hours a week, while Polish lessons were limited to two hours a week. The sisters also did not receive permission from the state author-

${ }^{33}$ In the mid-15th century, Szymanów belonged to the dukes of Mazovia. In 1435 it was sold to Abraham Pawłowski from Gnatowice. In the following centuries, many changes of ownership have taken place, and the property belonged to Sanguszko, Kronenberg,Lubienski and Lubomirski families. In the years 1898-1902, Duke Konstanty Lubomirski built a palace in Szymanów, which he decided to sell, due to the failure of his matrimonial plans and the related travel abroad. After: KOSYRA-CIEŚLAK, H., SZYMCZAK, R., Poszłam siać do Polski... i wzeszło, vol. 2, Szymanów 2005, pp. 99-100.

34 SOŁTAN, M.A., CIC, Człowiek, op. cit., pp. 85-89

${ }^{35}$ DAROWSKA, M., After: SKÓRZEWSKA, S.G., Zapiski, op. cit., vol. 12.

36 SZEMBEK, K., NOWOSIELECKA, C., CIC, Pięćdziesięciolecie Zakładu Sióstr Niep. Poczęcia Najśw. Panny Maryi w Szymanowie 1908-1958, pp. 4-5. 
ities to launch a fourth grade, so they conducted the classes "in secret". Exposed to numerous inspections, the sisters introduced two curricula and two types of textbooks, as well as an official and an actual timetable. Mrs Ciechanowska tried to counteract the defamatory opinions of Inspector Kujałowicz in St Petersburg, among other things by inviting significant persons to Szymanów, but it was not easy for the sisters to conduct educational activities in the Kingdom ${ }^{37}$. However, they could not stop their work because of the huge needs of the local community. That is why Mother Marcelina decided to expand the existing palace building, which turned out to be too small for the needs of the convent and the school. She personally laid a blessed cornerstone and the first brick under the new wing of the house. Two weeks later, she left Szymanów and never returned there again. She left her last and beloved foundation to God's care, believing that it would survive any repressions from the Russian Government ${ }^{38}$.

\section{Blessed Marcelina Dąbrowska's views on education}

Mother Marcelina did not have any pedagogical training when she started working and teaching in Jazłowiec. However, she confided in God, who assured her that He would teach her to lead a congregation and support her in the realisation of educational work. She was also aware of the importance of the task at hand, because, as she said, "it is the upbringing that roots the principles, forms the foundations for life, teaches how to live, and forms a being according to God's thought" 39 .

Mother Marcelina's perspective on the issue of upbringing was progressive at that time. She believed that "upbringing is the action of a rational being on another being similar to oneself, in order to develop and shape their physical, mental and moral abilities, to enable them to work on answering their calling and God's thought" 40 . Thus, in accordance with her assumptions, upbringing meant a comprehensive development of the student and mutual cooperation with the educator, not the forced shaping of children. It was to serve the purpose of discovering and fulfilling God's plan by the student.

In an effort to educate girls so as to enable them to understand their calling and prepare them for living in a given social and political reality, in 1872 Mother Marcelina established four main educational principles, which, by forming an inseparable whole, were to be the foundation of the nuns' educational work. The first of them was: "God is all - by all things unto God" 41 . It stemmed from her conviction that "human beings are created by

37 SOŁTAN, M.A., CIC, Matka. Życie i, op. cit., pp. 253-254.

38 JARZĄBEK, A., CIC, Życie, myśl i dzieło matki Marceliny Darowskiej współzałożycielki Zgromadzenia Sióstr Niepokalanek, Warsaw 1990, p. 19.

39 DAROWSKA, M., List do s. Karoli, 03.07.1906, ISCA, sign. P.44.3.I.336.

${ }^{40}$ SKÓRZEWSKA G., Pedagogika, Podręcznik opracowany na podstawie notatek z konferencji i wyktadów m. Marceliny Darowskiej, przez nia autoryzowany, Jazłowiec 1911, p. 1.

${ }^{41}$ DAROWSKA, M., Kartki, part I, chapter XII, ISCA, sign. P.20.5.I.1. 
God and for God, God provides them everything that they need and they depend on God; they are like God; they need God, seek Him and turn towards Him with their very nature. This relationship is the essence of every creation, and it binds God to the masterpiece of His hand" ${ }^{42}$. Therefore, according to the Mother Superior, the most important task of educators was to help children discover the closeness of God and to learn how to function in this new reality. Mother Marcelina expressed this in the following way: "love children's souls, teach them to love God and live for Him. Give them God in all things, and you will secure them and enrich them for life, for eternity; love them, for God loves them and they were entrusted to you by Him. You are their liaison with the Lord: work with Him"43.

Bearing in mind the overarching goal of knowing God and reconciliation with Him, Mother Marcelina set out the necessary measures that would lead to its realisation. Among them, she listed the knowledge of the Creator, faith (realised through prayer and actions in life) and participation in spiritual life (primarily by receiving the Holy Sacraments). She pointed out that, after teaching religion, prayer in particular is an important element of a good Christian life, because it ensures an inner balance and leads to openness towards God and the needs of others. That is why she encouraged the students: "learn to talk with Him, present your worries to Him and communicate with Him on each new day. Ask for everything you need, think about fulfilling your obligations, make good declarations"44.

Mother Darowska also appreciated the value of retreats, treating them as an important means of working on spiritual development. This is evidenced by her statement: "I do not know any spiritual exercises more abundant in grace and fruit, with better effects than retreats. [...] Sometimes good retreats are the foundation of the whole building of perfection, of all our spiritual life; just one retreat can suffice for the entirety of our life..."45. However, the use of this religious aid always required a thorough reflection, and taking under consideration the needs of a given soul.

Having in mind the additional support for the spiritual development of the students, the Mother Superior established the Combined Congregation of the Children of Mary Immaculate. The girls who belonged to the association were supposed to better themselves, that is, to live with God and renounce themselves. Before entering into the Congregation, the student had to prepare herself adequately and reach an appropriate level of spiritual development, meet the high demands and renounce belonging to any non-Catholic societies, as well as commit their lives "to strengthening Catholicism, spreading it and defending it with their example" ${ }^{46}$. Mother Marcelina saw the value of the formation of girls' religious attitudes through participation in the association, which is why she additionally edited the Książka do nabożeństwa Dzieci Maryi Niepokalanie poczętej ${ }^{47}$ (Book of Prayer for

\footnotetext{
${ }^{42}$ Eadem, Kartki, part II, chapter I, ISCA, sign.. P. 20.5. I. 2.

43 Eadem, Rekolekcje Kapitulne, 1909, lesson III, ISCA, sign. P. 20a. 1.IV.4.

44 Eadem, Rekolekcje dla wychodzacych z zakładu panienek, 1880, lesson VI, ISCA, no signature.

${ }^{45}$ KOSYRA-CIEŚlaK, H., SZYMCZAK, R., Poszłam siać, op. cit., vol. 1, p. 392.

46 Ibidem, p. 139.

${ }^{47}$ DAROWSKA, M., Książka do nabożeństwa Dzieci Maryi Niepokalanie Poczętej, Brody 1909.
} 
the Children of Mary Immaculate), in which she included various prayers, excerpts from the Scripture, services and religious songs. All the activities undertaken in congregation schools were intended to prepare girls for adult lives, so that they could fulfil their calling in a Christian spirit and realise the idea of building the Kingdom of God on earth.

The second most important educational principle of Mother Marcelina was: "God made us Poles"48. In this simple statement, Mother Marcelina included the truth she expressed in her will: "in God's works, nothing happens without a thought. It is not without thought that humanity divided itself into nations, it is no coincidence that the Congregation for the Kingdom of God was built in Poland, and was entrusted by the Providence to Poles. God's thoughts must not be turned away, because that would be the sin of sacrilege. Therefore, in our upbringing we have to respect our nationality, this quality of God's thought in the peoples; to cleanse it in the children entrusted to us from any foreign influences by developing its understanding and through love for it. We should, in a word, educate our students in Polish - to be Poles, without disregarding anything good and beautiful given to us by foreign countries. This is the principle of our schools in Poland"49. According to the Mother Superior, each nation, functioning at a certain point in time in history, has its own individual destiny to fulfil. Citizens are therefore left to discover and carry it out That is why the Mother Superior recommended developing a well-understood patriotism in children.

In relation to the Polish nation, the Mother Superior saw God's will in defending the "truth and the Church" 50 . Truth has always been a paramount value for her, so she did not accept any manifestation of despotism and enslavement, for they destroyed the truth. The defence of the Church in relation to the Congregation meant fervent prayer and obedience to the Pope. She observed with great sadness that there was a lack of national awareness in society, and even among the sisters she did not see a deep understanding of their duty for the country. As a result, she tried to show them what true love for the homeland was about. She urged them to love their homeland "not only because of the fact that it is ours, but also because it is also God's land, that was given to us by the Lord. [...] Let us work for the country not only because it is the land of our fathers and mothers, but also because it is the place given to us by the Creator, to fulfil his plan" ${ }^{51}$. The relationship between humans and their homeland should therefore have a religious character, since it is a gift from God.

Mother Marcelina also wrote: "Our task is to preserve the mother tongue and customs, type and nature in the young generation that was entrusted to us, purifying them from every influence that is human in nature, and that is Satan's work" 52 . This task was accomplished through patriotic education, which, in the congregation schools, was "interwoven" in a number of compulsory school subjects. This was made possible thanks to the fact that

\footnotetext{
${ }^{48}$ Eadem, Kartki, part I, chapter XII.

49 Eadem, Testament, Borynicze, 1884, ISCA, sign. P.20.4.I.1.

${ }^{50}$ Eadem, Komentarz do Reguły Braci Świeckich, 1874, ISCA, sign. P.20.6.II.4.

51 SKÓRZEWSKA, G., CIC, Pedagogika..., pp. 85-86.

52 DAROWSKA, M., O naukach $i$ wychowaniu, §7. ISCA, sigm. P.18.2.I.13.
} 
the sisters' developed their independent curricula. Patriotic accents were particularly evident during Polish language, history and geography classes ${ }^{53}$.

The mother tried to instil patriotism in the hearts of her students, so that in the future they would cherish everything that is Polish and pass it on in their own homes. She appealed to them: "if thanks to you, the number of righteous, Christian families grows, a new force for the country will rise. Now, the world is corrupt because the family has fallen: its character has diminished - the spirit has disappeared - it is misunderstood and disrespected. Your task is to lift it up, carry it and put it in its right place. This is your task, my dear students - you need to live for God - to see Poland reborn" ${ }^{54}$. The Mother Superior believed that the Sisters would contribute to the revival of their homeland through positive influence on their husbands, as well as Christian and patriotic upbringing of their children.

The third educational principle formulated by the Mother Superior reads as follows: "faithfulness to the duties of the state and place, which are an expression of God's will for everyone" ${ }^{55}$. It stemmed from the conviction that every human being was created by God to carry out certain tasks in a particular period of history, nation and family. In Mother Marcelina's conviction, God has given every individual their own place in the world, and thus imposed His obligations that are essential for the attainment of the highest goal: "the duties are like railings on the way of life; whoever does not stick to them and wanders beyond them, will inevitably stray from the good road and will never reach their goal. Disregarding duties is tantamount to disregarding God, and losing sight of the goal is losing sight of $\operatorname{God}^{56}$.

Recognising the great importance of being diligent and being aware that it was not a part of the Polish nature, Mother Marcelina required the students to keep their promises and to diligently carry out all duties entrusted to them. In her opinion, a failure to perform the duties or to keep a promise was a matter of conscience and a sin. She also recommended sisters: "treat children lovingly and be strict when it comes to their duties, avoid being soft, avoid ignoring the smallest ones; pray that God may give what we are not be able to give" 57 . In practice, therefore, sisters were not to force children to fulfil their duties, but rather to develop a sense of "duty, diligence, sensitivity, etc., in them. An example and a friendly explanation of what you want to see in them, explanation in good moments, leading to friendly understanding" ${ }^{58}$. They were supposed to instil a love for rights and obligations in children, so that they would respect them out of conviction, rather than because they had to.

\footnotetext{
${ }^{53}$ Ibidem.

54 Eadem, Cztery Pogadanki rekolekcyjne, Jazłowiec, 1904, p. 35.

55 Eadem, Kartki, part I, chapter XII.

56 Ibidem.

${ }^{57}$ Eadem, List do s. Wandy, 27.IV.1888, ISCA, sign. P. 45. 2. IV.113.

${ }^{58}$ Eadem, List do s. Zofii, 13.XII.1902, ISCA, sign. P. 50. 4. II.30.
} 
The superior of the Congregation, when talking about girls' duties, took into account both religious and moral responsibilities as well as the household duties assigned to each woman. She recommended, therefore "that our children should be able to practice crafts and farm work, so that they can teach others or supervise the work, and should the need arise, be able to help themselves and earn their living" ${ }^{59}$. Mother Marcelina wanted to ensure that girls were prepared for a life in different conditions, also in a situation where they had to live on their own and sustain themselves. However, it was not a good form at that time to talk about paid work for girls from good homes, because the public did not yet accept women from higher classes working to earn their living.

Regardless of the conventions at the time, congregation schools prepared girls for managing servants, as well as doing household work on their own. They were taught cooking, making preserves, budgeting, sewing and women's works. This practice was not always met with understanding of the students' parents. Marcelina was met with comments that it was not advisable for the ladies to do work unworthy of their social class. Such an approach was completely alien to the Mother Superior, who believed that in order to be able to demand good work from others, it was first of all necessary to work well. She did not accept the lack of cleanliness, inability to organise work, laziness, lavish lifestyle and underpaying employees.

In the last principle of education, Mother Marcelina recommended: "teach children to think and to be aware of what they do, what they think and say, so that nothing is unsubstantiated, conflicted or devoid of purpose" ${ }^{\prime 60}$. This principle has been widely applied both in upbringing and in Immaculatine education. The following recommendation of the Mother Superior referred to it: "Sisters will pursue the way of reason to convince their children, because we do not need thoughtless machines, but wise and persistent women! We do not need submissive girls, we need women with a strong conviction, strong spirit and therefore strong influence - that is who you should prepare for the country!"61. Such demands could sound strange at that time, but Mother Marcelina insisted: "when developing one's mind, you should not lead them astray, give them a foundation of truth; do not excite their imagination - teach them to think, think logically, basing their conclusions and judgements not on hypotheses, but on the widely recognised truths, on experiments and experiences; teach them to realise, to think without conducting an unending analysis without reaching conclusions" $"$.

The superior wanted the students to be convinced that their knowledge, which they would pass on to others, was based on solid foundations. In the future, they should act on the basis of their own conviction - conscience, at the same time is their wisdom. The system of education applied in Congregation schools was designed in such a way as to foster the development of independent judgements and beliefs, acquisition of the ability to eval-

\footnotetext{
59 Eadem, O naukach $i$ wychowaniu, $\$ 17$.

${ }^{60}$ Eadem, Kartki, part I, chapter XII.

${ }^{61}$ Eadem, List do M. Józefy, 18.IV.1856, ISCA, sign. P.4.1.III.22.

${ }^{62}$ Eadem, List do S. Zofii, 11.X.1901, ISCA, sign. P.50.4.II.23.
} 
uate, analyse and synthesise, as well as the acquisition of the ability to discuss. In addition, it enabled them to achieve a valuable ability to look critically at one's own personality, assimilated knowledge or existing ideologies. In adult life, Immaculatine students were supposed to be women who have their own view of the world and express their own thoughts and opinions without feeling embarrassed.

The above principles formed the foundation of the educational work of the Sisters of the Immaculate Conception. Mother Marcelina emphasised, however, that every human being discovers their vocation throughout their life. Therefore, the essence of upbringing in Congregation schools was the emancipation of mind, heart and will, as well as preparing girls for improving themselves, understood as continuous work on themselves ${ }^{63}$.

\section{Conclusions}

Marcelina Darowska died on the 5th of January $1911^{64}$. However, the educational work she initiated continues to this day. Nowadays, the Sisters of the Immaculate Conception run schools and kindergartens in Jarosław, Nowy Sącz, Szymanów, Wałbrzych, Warsaw and Łomianki ${ }^{65}$, bringing up the next generations, according to the recommendations of their mother, in a Christian, patriotic and practical spirit. In their educational work, the Sisters implement the principles established by the Mother Superior and her educational recommendations. Individualisation, patience and ensuring family atmosphere all occupy an important place in Immaculatine education. Despite the passage of time, the Mother Superior's postulates for the upbringing to be adapted to the needs and abilities of each and every student, and for the sisters to not focus on achieving results, but carry out their work with the belief that it will bring the intended results in the future, still remain valid.

Mother Marcelina had high expectations towards other nuns, which is evidenced by her words: "the teacher should develop without exertion, enrich without overburdening, bring up without exaltation; teach practicality without depriving of poetry, harden without making them dense, and refine them, while shielding them from exaggeration. Clean, sensitise conscience without allowing for scruples; teach love - without oversensitivity, devotion without ridicule. Get closer to them in games, without losing religious seriousness - without diminishing oneself - in order to be able to lift them up to the height of their task." ${ }^{66}$ At the same time, she was aware that Immaculatine education is connected with bearing a number of sacrifices and overcoming difficulties. However, she believed that, given the importance of raising girls as future members of families and society, it was the only right way to do it. This belief is shared by contemporary sisters who, having faced the

${ }^{63}$ JABŁOŃSKA-DEPTUŁA, E., Zakorzeniać nadzieję. M. Marcelina Darowska o rodzinie i dla rodzi$n y$, Lublin 2007, p. 21.

\footnotetext{
${ }^{64}$ Eadem, Marcelina ..., p. 149.

${ }^{65}$ www.niepokalanki.pl/index.php/dziela/szkoly-i-przedszkola (retrieved om 02.10.2016).

${ }^{66}$ DAROWSKA, M., Kartki, part I, chapter XII.
} 
need to update the Mother Superior's message to the current social reality, remain faithful to her key assumptions and have been bringing up children for 150 years in a unique Immaculatine spirit.

\section{Works cited}

\section{Archive sources}

DAROWSKA, M., Coś co poprzedziło. Autobiografia (Kilka lat z życia Matki Marceliny przez nia same spisane), Immaculatine Sisters Congregation Archive, sign. P.20.1.I.1.

DAROWSKA, M., Kartki, cz. I, Immaculatine Sisters Congregation Archive, sign. P.20.5.I.1.

DAROWSKA, M., Kartki, cz. II, Immaculatine Sisters Congregation Archive, sign. P. 20.5. I. 2.

DAROWSKA, M., Komentarz do Reguly Braci Świeckich, 1874 r., Immaculatine Sisters Congregation Archive, sign. P.20.6.II.4.

DAROWSKA, M., List do J. Felińskiego, 28.09.1876 r. (kopia), Immaculatine Sisters Congregation Archive, sign. P.8.2.I.46.

DAROWSKA, M., List do m. Józefy, 18.IV.1856, Immaculatine Sisters Congregation Archive, sign. P.4.1.III.22.

DAROWSKA, M., List do s. Filomeny, 3.XII.1901, Immaculatine Sisters Congregation Archive, sign. P.39.2.II.736.

DAROWSKA, M., List do s. Filomeny, 8.XII.1901, Immaculatine Sisters Congregation Archive, sign. P.39.2.II.737.

DAROWSKA, M., List do s. Józefy, 6.VII.1894, Immaculatine Sisters Congregation Archive, sign. P.36.4.II.692.

DAROWSKA, M., List do s. Karoli, 03.07.1906, Immaculatine Sisters Congregation Archive, sign. P.44.3.I.336.

DAROWSKA, M., List do s. Wandy, 27.IV.1888, Immaculatine Sisters Congregation Archive, sign. P. 45. 2. IV.113.

DAROWSKA, M., List do s. Zofii, 11.X.1901, Immaculatine Sisters Congregation Archive, sign. P.50.4.II.23.

DAROWSKA, M., List do s. Zofii, 13.XII.1902 r., Immaculatine Sisters Congregation Archive, sign. P. 50. 4. II.30.

DAROWSKA, M., O naukach $i$ wychowaniu, Immaculatine Sisters Congregation Archive, sign. P.18.2.I.13.

DAROWSKA, M., Rekolekcje Kapitulne 1909, Nauka III, Immaculatine Sisters Congregation Archive, sign. P. 20a. 1.IV.4.

DAROWSKA, M., Rekolekcje dla wychodzacych z zakładu panienek, 1880 r., Immaculatine Sisters Congregation Archive.

DAROWSKA, M., Testament, Borynicze 1884 r., Immaculatine Sisters Congregation Archive, sign. P.20.4.I.1.

SKÓRZEWSKA, G., CIC, Zapiski o Matce naszej, Immaculatine Sisters Congregation Archive, sign. F VII 1.

Wspomnienia Cezaryny z Kotowiczów Zakrzewskiej (siostry Marceliny). Podyktowane wnuczce Janinie i przestane siostrom niepokalankom w 1906 r., Immaculatine Sisters Congregation Archive, sign. P.93a.1.I.1. 


\section{Published works}

CHWALBA, A., Historia Polski 1795-1918, Kraków 2000.

DAROWSKA, M., Cztery Pogadanki rekolekcyjne, Jazłowiec 1904.

DAROWSKA, M., Ksią̇ka do nabożeństwa Dzieci Maryi Niepokalanie Poczętej, Brody 1909.

DOMASZEWSKA, M.E., GUŻDA, M.E., PINTSCHER, M.M., CIC (eds.), Stulecie Biatego Klasztoru i Szkoly Sióstr Niepokalanek w Nowym Saczu,

JABŁOŃSKA, E., "Zarys działalności Matki Marceliny Darowskiej na polu organizacji szkolnictwa żeńskiego 1863-1911", Nasza Przeszłość 1958, vol. 7.

JABŁOŃSKA-DEPTUŁA, E., Marcelina Darowska Niepokalanka 1827-1911, Lublin 2010.

JABŁOŃSKA-DEPTUŁA, E., Niepokalanki w polskim trwaniu, Niepokalanów 1993.

JABŁOŃSKA-DEPTUŁA, E., Zakorzeniać nadzieję. M. Marcelina Darowska o rodzinie i dla rodziny, Lublin 2007.

JARZĄBEK, A., CIC, Życie, myśl i dzieło matki Marceliny Darowskiej wspótzałożycielki Zgromadzenia Sióstr Niepokalanek, Warsaw 1990.

KOSYRA-CIEŚLAK, H., SZYMCZAK, R., Poszłam siać do Polski...i wzeszło, vol. 1, Szymanów 2004.

KOSYRA-CIEŚLAK, H., SZYMCZAK, R., Poszłam siać do Polski... i wzeszło, vol. 2, Szymanów 2005.

S. M. EWA OF DIVINE MERCY, Nauczycielka życia. W hołdzie wdzięczności bt. Matce Marcelinie Darowskiej, Szymanów 2009.

SKÓRZEWSKA, G., Pedagogika, Podręcznik opracowany na podstawie notatek z konferencji i wyktadów m. Marceliny Darowskiej, przez nia autoryzowany, Jazłowiec, 1911.

SOŁTAN, M.A., CIC, Człowiek wielkich pragnień. Matka Marcelina Darowska 1827-1911, Szymanów 1977.

SOŁTAN, M.A., CIC, Matka Marcelina Darowska (1827-1911), [in:] Chrześcijanie B. BEJZE (ed.), vol. 4, Warsaw 1980.

SOŁTAN, M.A., CIC, Stużebnica boża Marcelina Darowska, [in:] Polscy święci, J.R. BAR (ed.), vol. 8, Warsaw, 1987.

SZEMBEK, Z., CIC, Jazłowiec, Jazłowiec 1938.

SZEMBEK, K., NOWOSIELECKA C., CIC, Pięćdziesięciolecie Zakładu Sióstr Niep. Poczęcia Najśw. Panny Maryi w Szymanowie 1908-1958.

www.niepokalanki.pl/index.php/dziela/szkoly-i-przedszkola (retrieved on 02.10.2016). 
